\title{
2018-2019 Antimicrobial Resistance Pattern in Bacterial Pneumonia at Dr. Soedarsono Hospital Pasuruan
}

\author{
Felicia Susanto ${ }^{1}$, Catur Elvi Purnamawati ${ }^{2}$, Devvi Riasari ${ }^{3}$ \\ ${ }^{1}$ General Practitioner, Dr. Soedarsono Pasuruan Region General Hospital, Indonesia \\ ${ }^{2}$ Pulmonology and Respiratory Medicine, Dr. Soedarsono Pasuruan Region General Hospital, Indonesia \\ ${ }^{3}$ Clinical Pathology and Laboratory Medicine ,Dr. Soedarsono Pasuruan Region General Hospital, Indonesia
}

\begin{abstract}
Pneumonia is the ninth most common disease in dr. Soedarsono Pasuruan Region General Hospital. The resistance of Klebsiella pneumoniae to third-generation Cephalosporins and Streptococcus pneumonia to Penicillin were the topics discussed on World Health Organization's (WHO) global report for antimicrobial resistance. This study purpose is to analyze the microbial pattern and antimicrobial resistance of bacterial pneumonia from sputum culture. This is a descriptive retrospective study with a total of 59 requests for sputum culture which included a clinical diagnosis of pneumonia. There are 37 male (63\%) and 22 female (37\%) with the most age group was adult (18-59 years) 39 people (66\%) included in this study. Gram-negative bacteria are more common as the cause of pneumonia than gram-positive. Gramnegative bacteria that caused pneumonia in this study are Klebsiella pneumoniae (25.4\%), Acinetobacter baumannii (15.3\%), dan Enterobacter cloacae complex (15.3\%). Gram-positive are Staphylococcus haemolyticus (11.9\%), Staphylococcus aureus $(8.5 \%)$, and Staphylococcus epidermidis (8.5\%). The most antimicrobial resistance in gram-negative bacteria is Ampicillin (94.3\%) and gram-positive bacteria are Benzylpenicillin (94.1\%). The number resistance of Penicillin in gram-negative and gram-positive was high; therefore empirical therapy for pneumonia still uses broad-spectrum antimicrobial like beta-lactam.
\end{abstract}

MRJ 2020; 2(1):41-48

Keywords: antimicrobial resistance, pneumonia, microbial pattern, sputum culture

\section{Introduction}

The lung is an organ that prone to the infection because of its contact with particle, noxious gas, and infectious organism in the air directly. Lower respiratory infection kills more people than Human Immunodeficiency Virus (HIV), Tuberculosis (TB), and malaria. The results of therapy depend on organism virulence and inflammatory response of the respiratory tract. ${ }^{1}$ Pneumonia is inflammation of lung parenchyma caused by various microorganisms (bacteria, viral, fungi, parasite). Lower respiratory infection including Community-Acquired Pneumonia (CAP) placed number three as the most disease caused death all around the world. In Indonesia, pneumonia has the highest Crude Fatality Rate (CFR) $7.6 \%$ than other diseases. ${ }^{2}$ Prevalence pneumonia in East Java placed number two out of thirtythree provinces in Indonesia on $2018 .^{3}$

*Corresponding author:

Felicia Susanto ( feliciasusanto.7@gmail.com)

Dr. Soedarsono Pasuruan Region General Hospital, Indonesia 
Respiratory tract infection is the most diagnosis that made by Public Health Center in Pasuruan. ${ }^{4}$ Pneumonia included on the list as ten most disease hospitalized at RSUD Dr. Soedarsono Pasuruan. $^{5}$

Surveillance microbial and antimicrobial sensitivity in type $\mathrm{C}$ hospital in Indonesia describes the most five of gram-negative bacteria in sputum culture are Klebsiella pneumonia (K. pneumonia), Acinetobacter baumanni (A. baumanni), Escherichia coli (E.coli), Pseudomonas aeruginosa (P. Aeruginosa), and Enterobacter cloacae (E. cloacae). The most five of grampositive are Streptococcus viridans (S. viridans), Staphylococcus haemolyticus (S. haemolyticus), Streptococcus mitis (S. mitis), Staphylococcus aerus (S. aureus), dan Staphylococcus epidermidis (S. epidermidis). ${ }^{6}$

There are 700.000 people died every year because of antimicrobial resistance. The resistant microorganism has massive spread all around the world, estimated on 2050 antibiotic resistance's death rate is more than cancer. ${ }^{7}$ Empiric therapy for pneumonia is broad-spectrum antimicrobial like beta-lactam, macrolide, and fluoroquinolone respiratory. Recommendation antimicrobial for gram-negative community-acquired pneumonia are third-generation cephalosporins, fluoroquinolone, and carbapenem for Extended Spectrum Beta-Lactamase (ESBL). The recommendation for grampositive are beta-lactam penicillin but if patient allergic to penicillin there are vancomycin and clindamycin., ${ }^{8,9}$ Resistance $K$. pneumonia to thirdgeneration Cephalosporin and $S$. pneumonia to Penicillin were discussed on WHO Global Action Plan on Antimicrobial Resistance (GAPAMR). ${ }^{10}$ This study is the implementation of GAPAMR and Minister of Health Regulation Number 8 in 2015 about Preventive and Control of Antimicrobial Resistance in Hospital by established microbial pattern and antimicrobial resistance in RSUD Dr. Soedarsono Pasuruan. ${ }^{11}$

\section{Design and Method}

This is descriptive retrospective study was conducted at Microbiology Laboratorium Dr. Soedarsono Hospital Pasuruan. There are 59 requests for sputum culture which included a clinical diagnosis of pneumonia from July 2018 June 2019. Data sputum culture (isolates and sensitivity results) and demographic 
(age and sex) were extracted from laboratory records.

\section{Result}

Demographic

Fifty nine samples with a clinical diagnosis of pneumonia were requested for sputum culture from July 2018 - June 2019 (Table 1). The mean of age is 51.5 years old with the most group from the population in this study was $39(66 \%)$ adult persons (18-59 years). Male with pneumonia were diagnosed greater than female in this study.

Table 1. Demographic baseline $(\mathrm{N}=59)$

\begin{tabular}{lcc}
\hline & Variable & Result \\
\hline \multirow{3}{*}{ Age } & Mean & 51,46 \\
& Child $(5-17)$ & $2(3,40 \%)$ \\
& Adult (18-59) & $39(66,10 \%)$ \\
Sex & Elderly $(>60)$ & $18(30,50 \%)$ \\
& Men & $37(62,71 \%)$ \\
\hline
\end{tabular}

Microbial Pattern

Sputum culture in dr. Soedarsono

Region General Hospital from July 2018- June 2019 shows that gramnegative bacteria (71.2\%) caused pneumonia more than gram-positive (28.8\%). The most common etiology of gram-negative pneumonia is $\mathrm{K}$. pneumoniae (25.4\%), A. baumannii (15.3\%), and Enterobacter cloacae complex (15.3\%) (Table 2). Etiology of gram-positive pneumonia is $\mathrm{S}$. haemolyticus (41,2\%), S. aureus (29.4\%), and S. epidermidis (29.4\%) (Table 3).

Table 2. Microbial Pattern Gram-Negative Bacteria ( $\mathrm{N}=42)$

\begin{tabular}{lcr}
\hline \multicolumn{1}{c}{ Gram Negative Bacteria } & $\mathrm{n}$ & Percentage (\%) \\
\hline Klebsiella pneumoniae ssp pneumoniae & 15 & 35.71 \\
Acinetobacter baumannii & 9 & 21.43 \\
Enterobacter cloacae complex & 9 & 21.43 \\
Pseudomonas aeruginosa & 5 & 11.90 \\
Escherichia coli & 3 & 7.14 \\
Achromobacter xylosoxidans & 1 & 2.38 \\
\hline
\end{tabular}


Table 3. Microbial Pattern Gram-Positive Bacteria ( $\mathrm{N}=17)$

\begin{tabular}{llc}
\hline \multicolumn{1}{c}{ Gram Positive Bacteria } & $\mathrm{n}$ & Percentage (\%) \\
\hline Staphylococcus haemolyticus & 7 & 41.18 \\
Staphylococcus aureus & 5 & 29.41 \\
Staphylococcus epidermidis & 5 & 29.41 \\
\hline
\end{tabular}

Antimicrobial Resistance

(46.2\%) (Graphic 1). The antimicrobial The antimicrobial resistance of Gramnegative bacteria that caused pneumonia is Ampicillin (94.3\%), Cefazolin (87.5\%), and Ampicillin/ sulbactam resistance of Gram-positive bacteria to Benzylpenicillin, Oxacillin, and Tetracycline are $58.8 \%, 76.5 \%$, and $94.1 \%$ respectively (Graphic 2).

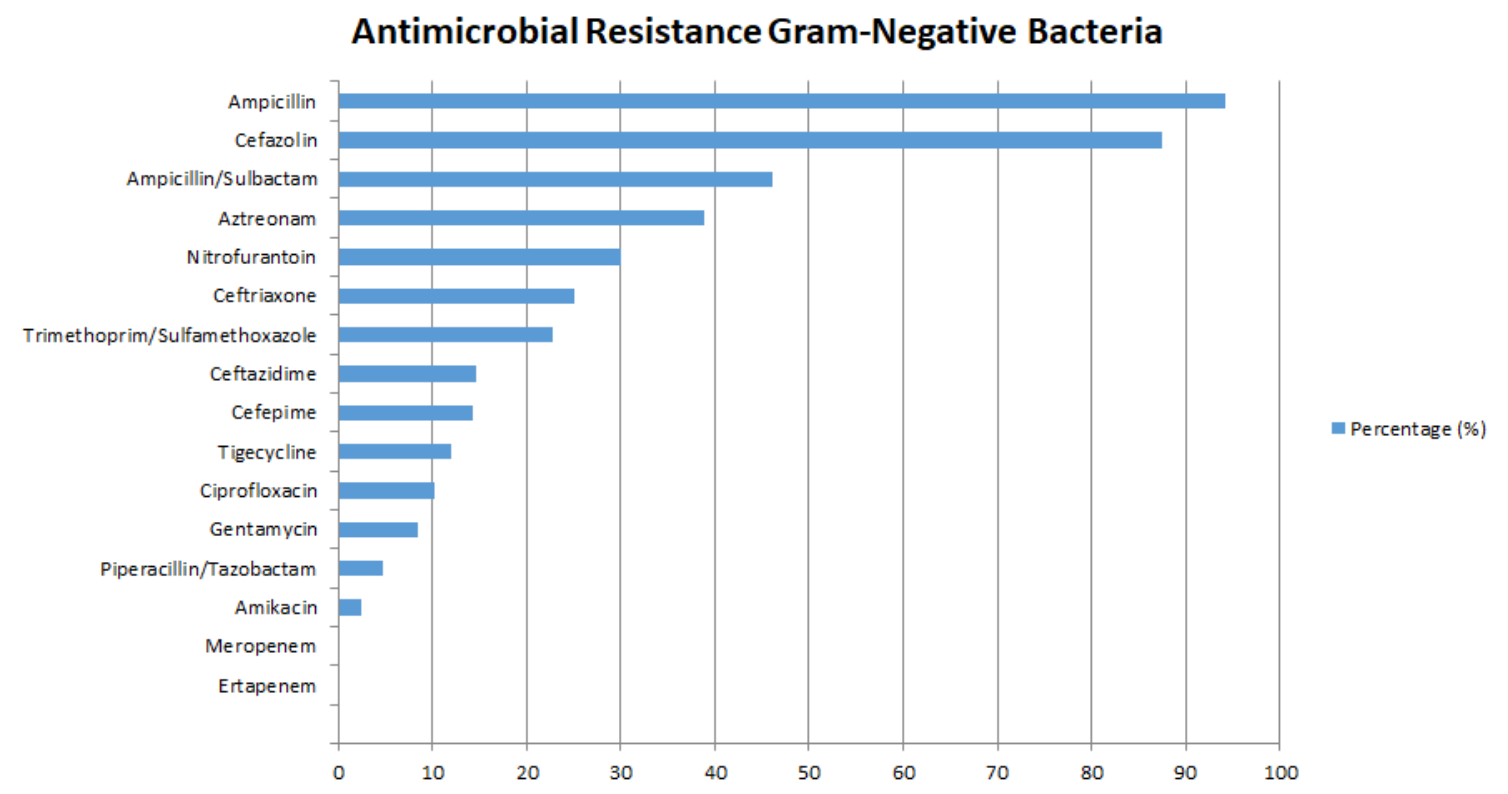

Graphic 1. Antimicrobial Resistance Gram Negative Bacteria

Source : this study 


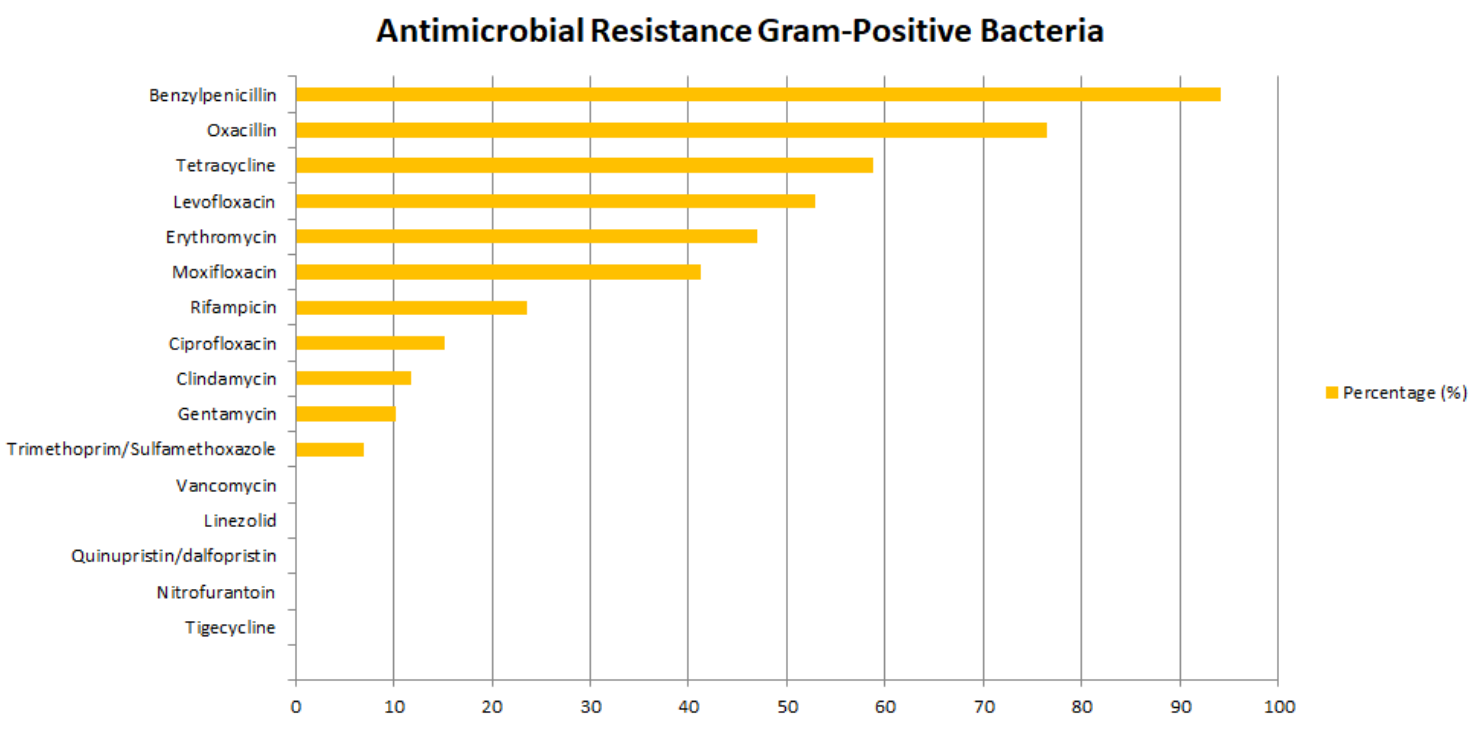

Graphic 2. Antimicrobial Resistance Gram Positive Bacteria

Source : this study

\section{Discussion}

The most age group that hospitalized with pneumonia in this study is adult (18-59 years) with mean age 51.5 years old. This age group has the same result as Indonesia Primary Health Research 2018. ${ }^{3}$ Pneumonia often affects infants and elderly due to weakness (innate and adaptive) of the immune system and increased asymptomatic aspirations in this age group. But the result of this study has different result because infant and elderly have lower cough response that making difficult to collect a good sputum sample. Therefore elderly hospitalization rates in Indonesia lower than the adult's age group because they usually self-medicated themselves. ${ }^{12}$
Men diagnosed pneumonia greater than women in this study. The risk factor that made men more prone to pneumonia are smoking and hormone. Men smoking tobacco more often than women. ${ }^{2}$ Tobacco smoking increases susceptibility to bacterial infection because morphological changes in the epithelium of the bronchial mucosa, with loss of cilia, mucous gland hypertrophy, increased goblet cells, and inhibits some of the key functions of the innate and adaptive response that may favor the presence and spread of microbes in the bronchial tree. ${ }^{13}$ Estrogen in women has a protective factor from pneumonia because promotes greater bacterial clearance, diminished lung 
inflammation, and better survival. In vitro, lung macrophages from female mice and humans show the better killing of ingested bacteria by role for estrogenmediated activation of lung macrophage nitric oxide synthase-3 (NOS3) enhanced macrophage bacterial killing, improved bacterial clearance, and increased host survival in both primary and secondary (post-influenza) pneumonia. $^{14}$

Sputum culture in RSUD dr. Soedarsono from July 2018- June 2019 shows that gram-negative bacteria $(71.19 \%)$ caused pneumonia more than gram-positive (28.81\%). Microbial pattern in gram-negative bacteria in this study has the same pattern as microbial pattern in type $\mathrm{C}$ hospital study before. ${ }^{6}$ But this microbial pattern of this study isn't the same as type A hospital in East Java. Microbial pattern Saiful Anwar Hospital Malang from JanuaryDecember 2012 are Staphylococcus coagulase-negative, Enterobacter gergoviae, and K. pneumonia. Therefore Doctor Soetomo Hospital Surabaya from December 2012 - November 2013 are Staphylococcus coagulase-negative, $K$. pneumonia, dan A. baumanni. ${ }^{2}$ Risk factor gram-negative pneumonia is Diabetes Mellitus (DM), HIV infection and alcoholism. ${ }^{15}$ Incidence DM placed number two as the most disease of outpatient and inward at Dr. Soedarsono Hospital. Higher blood glucose affects macrophage phagocytosis dysfunction, persisting pro-inflammatory status, and lower oxygen delivery supply to cells that enhanced anaerobic bacterial infection. ${ }^{16}$ Acquired Immunodeficiency Syndrome (AIDS) is the last stage of HIV infection, lower lymphocyte CD4+ count has a strong correlation with opportunistic infection caused death including pneumonia. ${ }^{17}$ The number of people living with HIV has continued to increase in Pasuruan City, in 2018 there are 77 patients. $^{5}$ Alcoholism is a potential risk factor for pneumonia because sedation effect which can reduce oropharyngeal tone leading to increased risk of aspiration microbe. High-level alcohol intake can modify alveolar macrophage function, hence diminishing pulmonary defense against infection. ${ }^{18}$

Antimicrobial resistance in gramnegative bacteria is Ampicillin (94.29\%), Cefazolin (87.5\%), and Ampicillin/sulbactam (46.15\%). Grampositive bacteria is Benzylpenicillin (94.12\%), Oxacillin (76.47\%), and Tetracycline (58.82\%). Ampicillin and benzylpenicillin are penicillin group of 
beta-lactam antibiotics. Mechanism of resistance to the penicillin and cephalosporins by the bacterial synthesizing beta-lactamase enzyme that hydrolyze beta-lactam ring. Antimicrobial resistance occurs naturally, but misuse and overuse of penicillin in humans and animals accelerating the process. Empiric therapy for pneumonia still use broad-spectrum antimicrobial like beta-lactam will less effective in Pasuruan City because high rate of Penicillin resistance in this study. ${ }^{19,20}$

\section{Conclusions}

There are 59 sputum culture at Dr. Soedarsono Pasuruan Hospital around July 2018-June 2019. Men diagnosed pneumonia greater than women and the most age group are adults (15-59 years). Gram-negative bacteria are more common as the cause of pneumonia than gram-positive. Gram-negative bacteria that cause pneumonia are $K$. pneumoniae, A. baumanni, and Enterobacter cloacae complex. Grampositive are S. haemolyticus, S. aureus, and S. epidermidis. The most antimicrobial resistance in gramnegative bacteria is Ampicillin and gram-positive bacteria are mrj.ub.ac.id |
Benzylpenicillin. The number resistance of Penicillin in gram-negative and grampositive was high.

\section{References}

1. Forum of International Respiratory Societies. The global impact of respiratory disease second edition. European Respiratory Society. 2017.

2. Indonesia Society of Respirology. Guideline for diagnosis and treatment community pneumonia in Indonesia. Second Edition. Jakarta: FKUI Publishing. 2014.

3. Ministry of Health Indonesia. Indonesia primary health research in 2018. Jakarta: Research and Development Agency Ministry of Health. 2019; 75-7, 237-48. https://labdata.litbang.depkes.go.id/ccount/cli ck.php?id=19

4. Health Department Pasuruan City. Pasuran city health profile 2017. Pasuruan: Health Department Pasuruan City. 2018; 22.

5. Statistics Pasuruan. Pasuruan municipality in figures 2019. Pasuruan: UD Rejo. 2019.

6. Dahesihdewi A, Adhi KS, Ida P. Surveillance microbial and sensitivity to antimicrobial based hospital's type in Indonesia 2017. Jakarta: Indonesian Society of clinical pathology and laboratory medicine. 2018.

7. Parathon H, Kuntaman K, Widiastoety TH, Muliawan BT, Karuniawati A, Qibtiyah M, et al. Progress towards antimicrobial resistance containment and control in Indonesia. BMJ. 2017; 358:31. https://www.ncbi.nlm.nih.gov/pubmed/28874 346

8. Mandell LA, Wunderink RG, Anzueto A, Bartlett JG, Campbell GD, Dean NC, et al. Infectious Diseases Society of America/American Thoracic Society consensus guidelines on the management of community-acquired pneumonia in adults. Clin Infect Dis. 2007; 44: S27-72. https://www.thoracic.org/statements/resource s/mtpi/idsaats-cap.pdf

9. Perez-Jorge EV, Burdette SD. Antibiotic therapy for positive blood cultures. Available from:

https://www.antimicrobe.org/new/e38rev2.as $\mathrm{p}$

10. WHO. Antimicrobial resistance: global report on surveillance. Geneva: WHO. 2014. www.who.int/drugresistance/documents/surv eillancereport/en/ 
11. Ministry of Health. Minister of Health Regulation Number 8 in 2015 about Preventive and Control of Antimicrobial Resistance in Hospital. Jakarta: Ministry of Health. 2015.

12. Ministry of Health Indonesia. Elderly analysis in Indonesia. Jakarta: Data Center and The Information Ministry of Health. 2017.

https://pusdatin.kemkes.go.id/article/view/18 012600001/analisis-lansia-di-indonesia2017.html

13. Almirall J, Jose B, Salvador B. Communityacquired pneumonia among smokers. Arch Bronconeumol. 2014;50:250-54. https://www.archbronconeumol.org/encommunity-acquired-pneumonia-amongsmokers-articulo-resumenS1579212914001256

14. Yang Z, Yuh-Chin TH, Henry K, Rini DC, Hartmut R, Paulus W, et al. Female resistance to pneumonia identifies lung macrophage nitric oxide Synthase-3 as a therapeutic target. eLife. 2014; 3. https://www.ncbi.nlm.nih.gov/pmc/articles/P MC4215537/

15. Grosso A, Angela F, Carlos ML. Community-acquired pneumonia due to gram-negative bacteria. Community Acquir Infect. $2015 ; 2: 117-22$ http://www.caijournal.com/article.asp?issn=2 2256482; year $=2015$; volume $=2$; issue $=4$; spage $=117$; epage $=122$; aulast $=$ Grosso

16. Falcone M, Giusy T, A Russo, Laura G, Elisa M, Giuliano B, et al. Hospitalization for pneumonia is associated with decreased 1year survival in patients with type 2 diabetes. Medicine. 2016; 95:5. https://www.ncbi.nlm.nih.gov/m/pubmed/268 44461/

17. Benito N, Moreno A, Miro JM, Torres A. Pulmonary infections in HIV-infected patients : an update in the 21 st century. Eur Respir J. 2012; 39:730- 45. https://erj.ersjournals.com/content/39/3/730

18. Simou E, Britton J, Leonardi BJ. Alcohol and the risk of pneumonia: a systematic review and meta-analysis. BMJ Open. 2018;8.https://bmjopen.bmj.com/content/8/8/ e022344.info

19. Brooks GF, Janet SB, Stephen AM. Jawetz, Melnick, \& Adelberg's Medical Microbiology. Jakarta: ECG. 2004.

20. Nikolaidis S, Favini S, Desse A. Resistance to antibiotics targeted to the bacterial cell wall. Protein Science. 2014;23:243-59. https://www.ncbi.nlm.nih.gov/pubmed/24375 653 